JFFI. 2019; 6(1) 325-333

www.jurnal.farmasi.umi.ac.id/index.php/fitofarmakaindonesia

\title{
KAJIAN KOMPOSISI KIMIA, NILAI NUTRISI, DAN ETNOFARMAKOLOGIS TANAMAN GENUS KENARI
}

\author{
Hamidah Rahman ${ }^{1 *}$, Kusnandar Anggadiredja², Tutus Gusdinar², Johnner P Sitompul ${ }^{3}$, \\ A.R. Ryadin ${ }^{4}$ \\ ${ }^{1}$ Program Studi Kesehatan Masyarakat, Fakultas Ilmu Kesehatan, Universitas Muhammadiyah \\ Maluku Utara, Ternate, Maluku Utara, Indonesia \\ ${ }^{2}$ Sekolah Farmasi, Institut Teknologi Bandung, Bandung, Jawa Barat, Indonesia \\ ${ }^{3}$ Program Studi Teknik Kimia, Fakultas Teknologi Industri, Institut Teknologi Bandung, Jawa \\ Barat, Indonesia \\ ${ }^{4}$ Program Studi Kehutanan, Fakultas Pertanian, Universitas Khairun, Ternate, \\ Maluku Utara, Indonesia \\ "hamidahr42@gmail.com
}

Submission Date: 08-11-2018; $\quad$ Review Completed: 19-12-2018; $\quad$ Accepted Date: 13-01-2019

\begin{abstract}
One species of canarium genus is Canarium indicum $\mathrm{L}$ which is an original plant from Indonesia. Utilization of some canarium nut species which spread around the world had been recognized, such as a source of nutritious food as well as its potency as raw material of medicine based on evidence-based scientific. In traditional medicine, was reported if canarium nut had been used for diabetes mellitus treatment, angina, hepatoprotective, antiinflammatory, antirheumatic, expectorant, etc. This article aims to review the chemical composition, nutrient values, and potency of canarium nut as the raw material of medicine. Scientific data were obtained from online search results. From the searching was found that at least eight species of canarium nut reported which is related to chemical composition and its nutrition which also provide ethnopharmacological benefits. Overall results, all identified canarium nut species have a favorable chemical composition and nutritional values that can be utilized as functional, nutritional and medicinal food. Therefore, the result of this study also indicates if the canarium nut from Indonesia, C. indicum L., has not been thoroughly studied. That indicates by the lack of scientific paper which presented about C. indicum from Indonesia.
\end{abstract}

Keywords: Canarium; Canarium indicum; bioactive compounds

\section{PENDAHULUAN}

Tanaman genus Canarium dari famili Burseraceae memiliki kurang lebih 100 spesies di seluruh dunia (Chua et al. 2015; Bai et al. 2017). Salah satu spesies dari genus Canarium adalah Canarium indicum L. merupakan tanaman asli di Indonesia khususnya di kawasan timur, seperti yang banyak tersebar di kepulauan Maluku (Thomson \& Evans 2006; Mogana \& Wiart 2011; Bai et al. 2017). Selain di Indonesia, Canarium indicum juga ditemukan di beberapa bagian negara lain yaitu di Papua New Guinea dengan nama lokal adalah galip, di pulau Solomon dengan nama ngali dan di Vanuatu dengan nama lokal nangai (Evans 1994). Beberapa nama lokal untuk kenari di Indonesia adalah kanari
(Sunda, Jawa), kanare (Bugis, Makassar), nyiha (Ternate, Tidore) (Heyne 1998).

Berdasarkan komposisi minyak dalam biji kenari, tanaman kenari dikelompokkan sebagai tree nuts dan dapat disebandingkan dengan kelompok tree nuts lain yang juga memiliki komposisi minyak cukup besar dalam bijinya, antara lain almond, cashew, hazelnuts, macadamia dan lain-lain (Djarkasi et al. 2011). Asam lemak dalam trigliserida minyak dari berbagai spesies kenari juga telah dilaporkan. Pada umumnya semua spesies kenari mengandung beberapa jenis asam lemak dan asam oleat sebagai asam lemak yang terbanyak dalam kenari yaitu berkisar 40-70\% (Leakey et al. 2008; Azlan et al. 2010; Pham \& Dumandan 2015; Rahman et al. 2015; Bai et al. 2017). Asam oleat menunjukkan 
sifat yang netral terhadap lipid plasma sehingga banyak digunakan dalam formulasi produk pangan (Dubois et al. 2007) dan memiliki aktivitas menurunkan level kolesterol plasma (Osborn \& Akoh 2002; Bruckner 2008). Asam oleat yang banyak terdapat dalam minyak zaitun diindikasikan dapat mencegah penyakit kardiovaskular (Massimo et al. 2009). Komposisi minyak yang cukup besar dalam biji kenari sehingga kenari berpeluang sebagai sumber minyak pangan (edible oil). Bagian dari biji kenari yang disebut kernel atau pulp juga dapat dikonsumsi langsung sebagai pangan camilan oleh masyarakat lokal penghasil kenari, antara lain di kawasan timur Indonesia (Djarkasi et al. 2011), di daerah Serawak Malaysia (Chew et al. 2011), dan Filipina (Millena \& Sagum 2018).

Selain biji kenari sebagai sumber pangan, pemanfaatan bagian lain dari tanaman kenari seperti batang, daun dan bagian eksokarp dari buah kenari juga telah dilaporkan, antara lain untuk tujuan pengobatan penyakit dan pewarna makanan alternatif. Tulisan ini bertujuan untuk mengkaji pemanfaatan kenari sebagai sumber pangan maupun sebagai bahan obat berdasarkan laporan publikasi yang memuat komposisi kimia, nilai nutrisi dan evidence-based medicine.

\section{METODE PENELITIAN}

Metode yang digunakan adalah kajian

sistematik (systematic review) dari hasil penelusuran

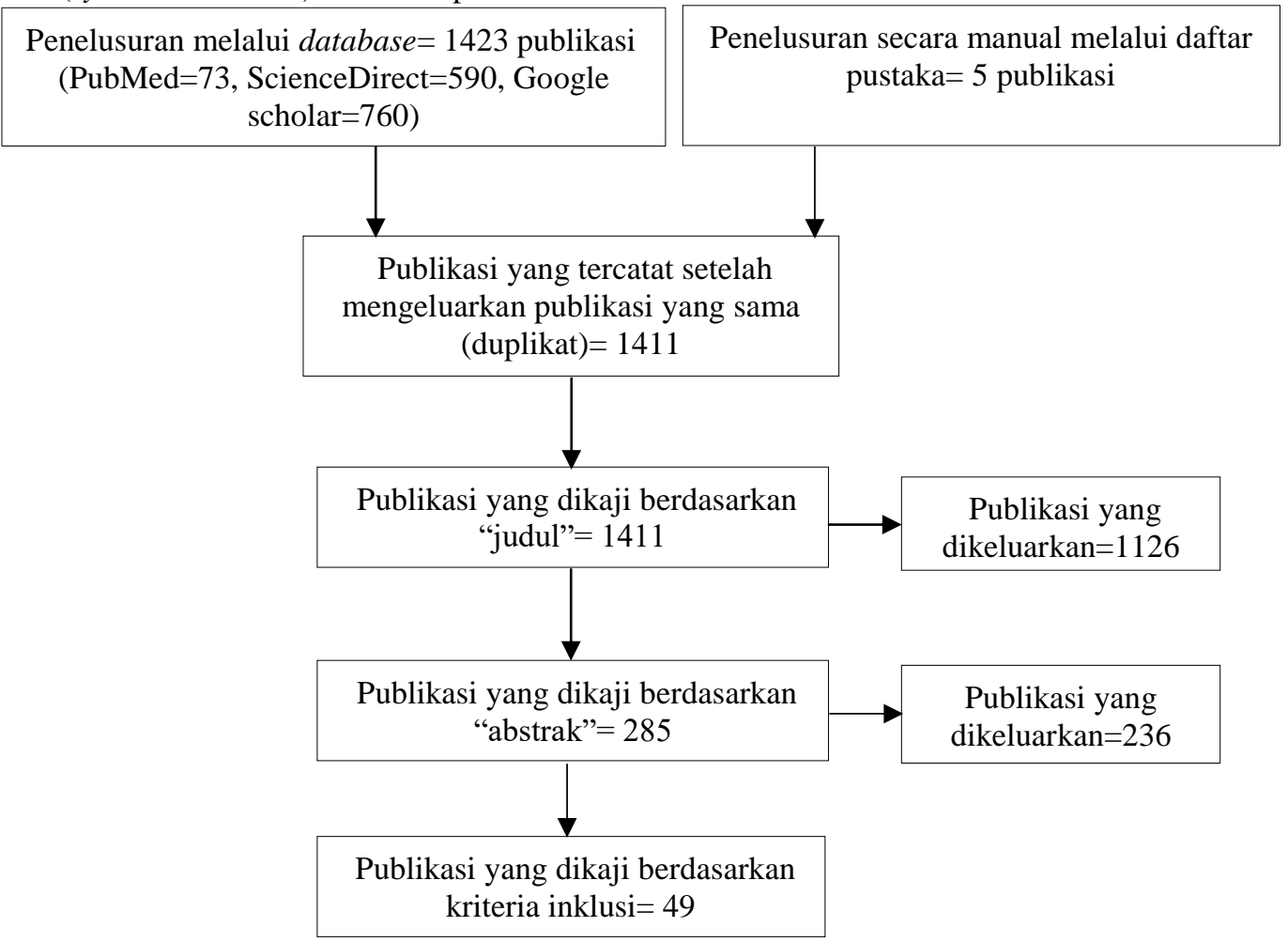

Gambar 1. Bagan alir tinjauan sistematik untuk genus canarium

Jurnal Fitofarmaka Indonesia, Vol. 6 No.1 scholar=760) secara online pada database PubMed, ScienceDirect dan Google Scholar. Pencarian menggunakan kata kunci "canarium". Kriteria inklusi yang digunakan adalah artikel ilmiah dari database online berupa original research atau research article yang melaporkan komposisi kimia, komposisi nutrisi dan etnofarmakologis dari genus canarium. Tidak ada batasan waktu publikasi untuk artikel yang dikaji. Kriteria eksklusi adalah artikel ilmiah yang dituliskan tidak menggunakan bahasa Inggris dan spesies kenari yang dilaporkan tergolong non-edible. Untuk mendapatkan data tambahan dilakukan penelusuran secara manual dengan menggunakan daftar referensi dari artikel yang dikaji.

\section{HASIL DAN PEMBAHASAN}

Berdasarkan hasil penelusuran telah diindentifikasi jumlah artikel ilmiah dari masingmasing penyedia database, yaitu dari PubMed= 73 publikasi, ScienceDirect $=590$ publikasi, Google scholar $=760$ publikasi. Selanjutnya dilakukan penghapusan dengan mengeluarkan artikel ilmiah yang sama termuat dalam ketiga pengindeks database tersebut, diperoleh total seluruh artikel adalah 4 artikel, sedangkan penelusuran secara manual diperoleh 5 artikel tambahan. Tahapan pengumpulan data seperti termuat pada gambar 1: 
Dari hasil identifikasi diperoleh sebanyak 49 publikasi yang dikaji sesuai dengan tujuan penelitian dan diperoleh setidaknya ada delapan spesies kenari yang dilaporkan, yaitu Canarium indicum, Canarium odontophyllum, Canarium patentinervium, Canarium ovatum, Canarium album, Canarium pimela, Canarium zeylanicum, dan Canarium schweinfurthii. Sebaran tanaman kenari tersebut dari berbagai negara, antara lain Indonesia, Papua New Guinea, Malaysia, Filipina, China, Sri Lanka dan wilayah Afrika.

Komposisi kimia dan komponen bioaktif pada spesies kenari yang dilaporkan adalah kelompok asam lemak (asam oleat, asam linoleat, asam linolenat, asam palmitoleat, asam palmitat, asam stearat, dan asam arachidat), dari kelompok asam amino (arginin, glutamin, asam aspartat, metionin, lisin), golongan sterol (stigmasterol dan kampesterol), triterpenoid, kelompok mineral (kalsium, natrium, kalium, magnesium, zinc, dan besi), senyawa antioksidan dari golongan fenolik (asam galat, asam elagat, brevifolin), flavonoid, tannin, dan senyawa oligosakarida.

Secara etnofarmakologis pemanfaatan spesies kenari yang dilaporkan adalah memiliki aktivitas sebagai antimikroba (Koudou et al. 2005; Mogana et al. 2011b; Basri \& Sandra 2016; Dzotam et al. 2016), mengatur kadar glukosa darah (Saari et al. 2017; Yeh et al., 2017), sebagai antiaterosklerosis (Shakirin et al. 2012a; Shakirin et al. 2012b), memiliki aktivitas sebagai antiinflamasi (Leakey et al. 2008; Mogana et al. 2013a; Mogana et al. 2013b), memiliki aktivitas antioksidan (Prasad et al. 2010; Chew et al. 2011; Djarkasi et al. 2011; Prasad et al. 2011; Arenas \& Trinidad 2017a; Arenas \& Trinidad 2017b) dan sebagai hepatoprotektif (Yeh et al. 2017). Pemanfaatan delapan spesies kenari dalam pengobatan dan sebagai sumber nutrisi pangan dirangkum pada tabel 1 .

\section{Canarium indicum}

Spesies kenari ini banyak dituliskan sebagai kenari yang berasal dari kawasan timur Indonesia (gambar 2) dan dimanfaatkan sebagai salah satu sumber pangan lokal (Thomson \& Evans 2006; Mongana \& Wiart 2011; Bai et al. 2017). Nama lain untuk Canarium indicum (CI) adalah Canarium amboinense Hochr, Canarium commune L., dan Canarium moluccanum Blume (Heyne 1998; Thomson \& Evans 2006). Boorsma (1914) menuliskan bahwa Canarium commune dimanfaatkan sebagai bahan pembuatan susu bayi. Hasil analisis komposisi dan distribusi posisi asam lemak dalam trigliserida CI (Rahman et al. 2016) mendukung pemanfaatan kenari sebagai bahan baku susu bayi karena memiliki kemiripan dengan trigliserida dalam air susu ibu, yaitu komposisi asam palmitat yang bermakna (Rahman et al., 2015). Asam lemak yang terbanyak dalam biji CI adalah asam oleat (Leakey et al. 2008; Djarkasi et al. 2011; Rahman et al. 2015; Bai et al.2017).

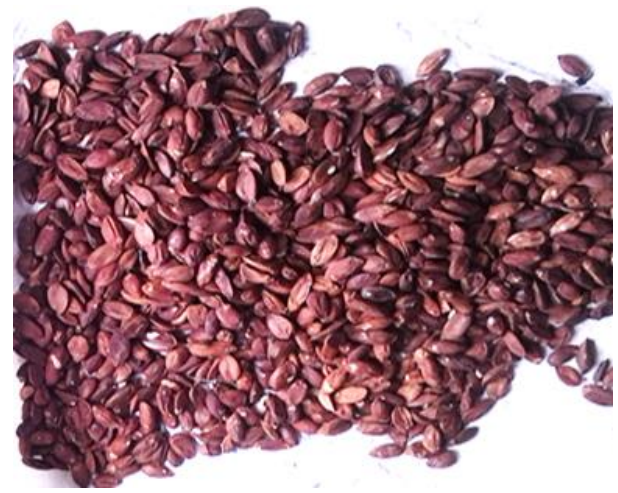

Gambar 2. Canarium indicum asal kepulauan Maluku

Komposisi asam amino terbesar dalam biji kenari adalah asam glutamat, lisin, asam aspartat dan arginin. Adanya asam glutamat yang banyak memberikan rasa gurih dari biji kenari. Jenis asam amino yang lengkap dalam biji CI (Djarkasi et al. 2011) menunjukkan bahwa CI dapat dimanfaatkan sebagai sumber pangan fungsional karena asam amino memiliki aktivitas mengatur fungsi fisiologi manusia sehingga dapat mengatur metabolisme untuk menjaga dan meningkatkan kesehatan (Betts \& Russell 2003; Wu 2013). 
Tabel 1. Data etnofarmakologis genus Canarium

\begin{tabular}{|c|c|c|c|c|}
\hline No & Nama Tanaman & Bagian Tanaman & Aktivitas & Referensi \\
\hline 1. & Canarium indicum $\mathrm{L}$. & Biji & $\begin{array}{l}\text { Antiinflamasi (uji in- } \\
\text { vitro); antioksidan } \\
\text { (uji in-vitro) }\end{array}$ & $\begin{array}{l}\text { Leakey et al. 2008; } \\
\text { Djarkasi et al. } 2011\end{array}$ \\
\hline 2. & odontophyllum & Daun, pericarp, buah & $\begin{array}{l}\text { Antibakteri, } \\
\text { antidiabetik, } \\
\text { antiaterosklerosis, } \\
\text { antioksidan }\end{array}$ & $\begin{array}{l}\text { Prasad } \text { et al. } 2010 ; \\
\text { Khoo et al. 2014; } \\
\text { Basri \& Sandra 2016; } \\
\text { Saari } \text { et al. } 2017\end{array}$ \\
\hline 3. & patentinervium & Daun, batang & $\begin{array}{l}\text { Antimikroba, } \\
\text { antioksidan, } \\
\text { antiinflamasi, } \\
\text { pengobatan penyakit } \\
\text { degeneratif }\end{array}$ & $\begin{array}{l}\text { Mogana et al. } 2011 \mathrm{~b} ; \\
\text { Mogana et al. } 2014\end{array}$ \\
\hline 4. & Canarium ovatum Engl. & Biji & $\begin{array}{l}\text { Antioksidan } \\
\text { (uji in-vitro \& in- } \\
\text { vivo); bahan pewarna } \\
\text { alami untuk pangan }\end{array}$ & $\begin{array}{l}\text { Arenas \& Trinidad } \\
\text { 2017a; Arenas } \\
\text { \&Trinidad 2017b; } \\
\text { Aril-dela } \text { et al. } 2018\end{array}$ \\
\hline 5. & Canarium album $\mathrm{L}$. & Buah & $\begin{array}{l}\text { Hepatoprotektif (uji } \\
\text { in-vitro \& in-vivo); } \\
\text { antidiabetik }\end{array}$ & $\begin{array}{l}\text { Yeh et al. 2017; Yeh } \\
\text { et al. } 2018\end{array}$ \\
\hline 6. & Canarium pimela $\mathrm{L}$. & Daun & Antioksidan & Wu et al. 2017 \\
\hline 7. & $\begin{array}{l}\text { Canarium zeylanicum } \\
\text { (Retz.) Blume }\end{array}$ & Biji & Antioksidan & $\begin{array}{l}\text { Seneviratne \& } \\
\text { Kotuwegedara } 2009\end{array}$ \\
\hline 8. & $\begin{array}{l}\text { Canarium } \\
\text { Engl. }\end{array}$ & $\begin{array}{l}\text { Kulit batang, } \\
\text { buah }\end{array}$ & $\begin{array}{l}\text { Antibakteri, } \\
\text { antikanker, analgesik, } \\
\text { antidiabetik, } \\
\text { antioksidan }\end{array}$ & $\begin{array}{l}\text { Koudou et al. 2005; } \\
\text { Kamtchouing et al. } \\
\text { 2006; Stangeland et } \\
\text { al. 2009; Kuete et al. } \\
\text { 2015; Seukep et al. } \\
\text { 2015; Dzotam et al. } \\
2016\end{array}$ \\
\hline
\end{tabular}

Uji aktivitas farmakologis secara in-vitro dari minyak biji CI menunjukkan bahwa minyak CI memiliki aktivitas menghambat produksi prostaglandin E2 sehingga memiliki aktvitas sebagai antiinflamasi (Leakey et al. 2008). Aktivitas antioksidan juga ditunjukkan oleh adanya komposisi golongan tokoferol dalam biji kenari (Djarkasi et al. 2011). Keunggulan dari CI adalah memiliki ukuran buah yang besar dibandingkan dengan spesies kenari lain sehingga CI dinilai lebih memiliki potensi ekonomi yang lebih baik (Djarkasi et al. 2011). Spesies kenari lainnya yang disebutkan merupakan kenari asli dari Indonesia adalah Canarium vulgare Leenh. (Lim 2011) saat ini belum banyak dilaporkan.

\section{Canarium odontophyllum}

Canarium odontophyllum (CO) adalah spesies kenari yang banyak tumbuh di daerah Serawak, Malaysia (Prasad et al. 2010; Shakirin et al. 2012b). CO memiliki nilai nutrisi dan memberikan keuntungan efek farmakologis (Basri \& Sandra 2016). Studi in-vivo pemberian ekstrak air daun CO pada kelompok tikus diabetes yang telah diinduksi dengan streptozotocin menunjukkan efek menurunkan kadar glukosa darah. Aktivitas CO sebagai hipoglikemia disebabkan oleh komposisi flavonoid, tannin, saponin, terpenoid, dan senyawa fenol dalam daun CO (Saari et al. 2017).

Aktivitas lain dari CO sebagai antibakteri khususnya terhadap golongan Methicillin-Resistant Staphylococcus aureus atau MRSA dari ekstrak methanol daun CO (Basri \& Sandra 2016). Khoo et al. (2014) juga melaporkan anthocyanins dari CO memiliki aktivitas cardioprotective yang diuji secara in-vitro, mempunyai aktivitas sebagai antioksidan yang dapat menghambat oksidasi pada sel darah dan bersifat antiaterosklerosis pada kelinci yang diberikan makanan tinggi kolesterol (Shakirin et al. 2012a; Shakirin et al. 2012b). 
Buah CO menunjukkan aktivitas sebagai antioksidan dengan uji in-vitro menggunakan pengujian 1,1-diphenyl-2-picryl hydrazyl (DPPH) dan Ferric Reducing Antioxidant Power (FRAP) sehingga dapat dimanfaatkan sebagai sumber antioksidan alami (Prasad et al. 2010, Shakirin et al. 2010; Prasad et al. 2011). Hasil penelitian Azlan et al. (2010) menunjukkan komposisi nutrisi yang baik dalam minyak $\mathrm{CO}$ sehingga terdapat peluang $\mathrm{CO}$ dimanfaatkan dalam industri pangan.

\section{Canarium patentinervium}

Canarium patentinervium (CP) adalah spesies kenari yang berasal dari Malaysia (Mogana et al. 2011b), meskipun demikian Heyne (1987) menuliskan bahwa CP ditemukan tumbuh di Indonesia yaitu di daerah Lematanghulu di pulau Sumatera dengan nama lokal teta tunju. Sistem pengobatan tradisional masyarakat Malaysia telah menggunakan jenis kenari ini untuk mengobati luka. Komposisi tannin dan flavonoid dalam ekstrak etanol daun dan kulit batang CP adalah sebagai komponen bioaktif antimikroba. Ekstrak daun CP menunjukkan aktivitas antimikroba pada bakteri gram positif yaitu untuk Staphylococcus aureus dan MethicillinResistant Staphylococcus aureus (MRSA) dan juga terhadap bakteri gram negatif dari Pseudomonas aeruginosa (Mogana et al. 2011b).

Ekstrak daun CP menunjukkan aktivitas kombinasi sebagai antiinflamasi dan antioksidan berdasarkan kemampuan menghambat enzim Cyclooxygenase (COX) dan 5-lipoxygenase (5-LOX). Hasil penelitian Mogana et al. (2013b) menyimpulkan bahwa komponen bioaktif dalam CP dapat dijadikan sebagai senyawa pemandu (lead compounds) untuk pengobatan inflamasi. Spesies CP juga berpeluang dimanfaatkan untuk pengobatan penyakit degeneratif, antara lain untuk penyakit Alzheimers. Hal ini dibuktikan oleh kemampuan menghambat enzim acetylcholinesterase (AChE). Demikian pula karena menunjukkan efek sebagai antikolinesterase maka ekstrak CP dapat juga dimanfaatkan sebagai antileshmanial untuk pengobatan parasit. Aktivitas ini dimungkinkan karena kandungan scopoletin dalam ekstrak daun CP (Mogana et al. 2014).

\section{Canarium ovatum}

Spesies Canarium ovatum (CO) adalah tanaman asli dari Filipina dengan sebutan masyarakat setempat adalah pili nut (Pham \& Dumandan 2015; Arenas \&Trinidad 2017; Aril-dela et al. 2018). Produk utama dari jenis kenari ini adalah minyak kenari yang dilaporkan memiliki komposisi asam lemak yang baik (Pham \& Dumandan 2015). Pili nut juga dilaporkan pemanfaatannya sebagai produk pangan yaitu pomace drink yang telah diuji in-vivo pada manusia dan menunjukkan peningkatan kadar polifenol dalam plasma manusia secara bermakna (Arenas \& Trinidad 2017b).

Kenari asal Filipina ini banyak dilaporkan pemanfaatannya untuk aplikasi pangan. Hasil analisis komposisi trigliserida dalam CO menunjukkan bahwa $\mathrm{CO}$ dapat dimanfaatkan sebagai alternatif untuk cocoa butter (Kakuda et al. 2000). Demikian pula dari hasil penelitian Millena \& Sagum (2018) menunjukkan bahwa CO sebagai sumber pangan bernutrisi karena komposisi mineral dalam $\mathrm{CO}$ memiliki bioavailabilitas yang baik. Hal ini dibuktikan dari uji in-vitro yang menunjukkan bahwa mineral dalam CO dapat diabsorpsi dengan baik.

\section{Canarium album}

Spesies Canarium album (CA) dikenal juga dengan nama Chinese olive adalah jenis kenari yang banyak dibudidayakan di negara China bagian selatan (Wen et al. 2013). Karakteristik CA banyak dilaporkan meliputi komposisi kimia, nilai nutrisi, penggunaannya dalam pengobatan tradisional China, dan keuntungan farmakologis melalui uji in-vitro maupun in-vivo hingga ke penelitian genetika spesies CA.

Identifikasi dan kuantifikasi tujuh senyawa fenolik dalam biji CA dilaporkan secara lengkap oleh He \& Xia (2007a). Demikian pula laporan komposisi nutrisi dalam biji CA antara lain adalah asam lemak, dengan komposisi terbanyak adalah asam linoleat, asam oleat dan asam stearat. Komposisi asam amino dalam biji CA terbanyak berturut-turut adalah asam glutamat, arginin, asam aspartat dan leusin (He \& Xia 2007b). Kuo et al. (2015) melaporkan komponen bioaktif dari total fenolik, total flavonoid, triterpenoid dan tannin dalam CA yang bertanggung jawab terhadap aktivitas antioksidan dari CA. Semua komponen bioaktif tersebut merupakan senyawa yang mampu mengurangi reaksi peroksidasi lipid. Aktivitas sebagai antiglycation dari ekstrak biji CA menunjukkan bahwa CA berpotensi sebagai antidiabetik dengan uji in-vitro. Yeh et al. (2017) dan Yeh et al. (2018) menguji ekstrak buah CA secara invitro dan in-vivo yang menunjukkan bahwa CA memiliki aktivitas memperbaiki metabolisme lipid sehingga dapat memperbaiki akumulasi lipid di hepar. Aktivitas ini disebabkan oleh komposisi polifenol dalam CA yang meregulasi gangguan metabolisme antara lain pada diabetes tipe 2 dan penyakit kardiovaskular.

Komponen bioaktif triterpen dalam CA menunjukkan efek hepatoprotektif yang diuji in-vitro dan in-vivo. Aktivitas ini terkait dengan efek antioksidan dari ektrak buah CA (Tamai et al. 1989; Ito et al. 1990), sedangkan komposisi tannin dalam 
daun, ranting dan kulit batang CA menunjukkan aktivitas sebagai antioksidan yang cukup baik (Zhang \& Lin 2008). Senyawa oligosakarida dilaporkan terdapat dalam buah CA memiliki aktivitas sebagai antioksidan dan memberikan efek prebiotik sehingga dapat dikembangkan sebagai pangan fungsional dan nutraseutikal (Wen et al. 2013).

\section{Canarium pimela}

Canarium pimela (CPi) atau black Chinese olive disebutkan berasal dari China Selatan dengan nama lokal wu lan (Lv et al. 2011; Wu et al. 2017). Tradisi pengobatan China telah memanfaatkan buah $\mathrm{CPi}$ untuk mengatasi pendarahan, mengurangi produksi dahak, mengurangi rasa nyeri dan inflamasi. Selain itu minyak buah CPi telah dimanfaatkan dalam industri pangan (Lv et al. 2011).

Spesies kenari ini dilaporkan memiliki komposisi nutrisi yang baik, yaitu kandungan asam lemak, asam amino dan mineral. Dari hasil analisis proksimat dan sifat fisiko-kimia dilaporkan bahwa minyak biji CPi memenuhi syarat sebagai edible oil atau minyak pangan (Lv et al. 2011). Wu et al. (2017) melaporkan komposisi senyawa bioaktif dalam CPi yaitu total fenol, flavonoid dan tannin memiliki aktivitas sebagai antioksidan sehingga dapat dimanfaatkan sebagai bahan baku farmasi untuk tujuan pengobatan hipertensi dan mencegah kerusakan akibat stres oksidatif.

\section{Canarium zeylanicum}

Jenis kenari ini merupakan tanaman endemis dari Sri Lanka. Minyak biji Canarium zeylanicum (CZ) telah dimanfaatkan secara tradisional oleh masyarakat setempat sebagai sumber pangan dan untuk tujuan pengobatan. Analisis fisikokimia minyak biji $\mathrm{CZ}$ menunjukkan bahwa minyak CZ memenuhi syarat sebagai edible oil. Komposisi asam lemak dalam minyak biji CZ terbesar berturut-turut adalah asam linolenat, asam linoleat dan asam oleat. Komposisi kimia lainnya yang dilaporkan adalah senyawa polifenol dan menunjukkan aktivitas sebagai antioksidan yang baik (Seneviratne \& Kotuwegedara 2009).

\section{Canarium schweinfurthii}

Spesies Canarium schweinfurthii (CS) adalah tanaman asli dari beberapa negara bagian Afrika termasuk negara Cameroon dengan nama lokal bele atau boluga dan biasa disebut juga African elemi (Youmsi e al. 2017). Dzotam et al. (2016) melaporkan komposisi kimia dalam buah kenari ini adalah golongan alkaloid, polifenol, flavonoid, kumarin, tannin, triterpen, sterol dan saponin yang memberikan aktivitas sebagai antibakteri untuk multi-drug resistant gram-negative bacteria.
Aktivitas sebagai antibakteri juga dilaporkan oleh Seukep et al. (2015), sedangkan Kuete et al. (2015) melaporkan bahwa hasil penapisan awal menunjukkan bahwa spesies CS memiliki aktivitas sebagai antikanker melalui uji sitotoksik in-vitro. Ekstrak methanol dari kulit batang CS menunjukkan aktivitas sebagai antidiabetik melalui uji in-vivo (Kamtchouing et al. 2006), sedangkan minyak esensial dari CS menunjukkan aktivitas sebagai analgesik (Koudou et al. 2005).

\section{KESIMPULAN}

Hasil penelusuran menggunakan metode kajian sistematik diketahui bahwa setidaknya ada delapan spesies dari genus Canarium dilaporkan memiliki aktivitas farmakologi. Dari penelusuran pustaka diketahui bahwa kajian aktivitas farmakologis yang paling banyak dilaporkan adalah dari spesies Canarium album dari China, sedangkan kajian kenari sebagai produk pangan bernutrisi paling banyak dilaporkan dari Canarium ovatum asal Filipina. Kenari asal Indonesia yaitu Canarium indicum berpeluang dimanfaatkan sebagai sumber pangan fungsional maupun untuk pengobatan sehingga diperlukan penelitian lebih banyak untuk mendukung pemanfaatan kenari khususnya yang berasal dari Indonesia. Demikian pula spesies kenari lainnya dari Inonesia yaitu Canarium vulgare diketahui masih kurang diteliti berdasarkan minimnya artikel yang memuat tentang Canarium vulgare.

\section{DAFTAR PUSTAKA}

Arenas, E.H. \& Trinidad, T.P., 2017a, 'Fate of polyphenols in pili (Canarium ovatum Engl.) pomace after in vitro simulated digestion', Asian Pac J Trop Biomed. 7, 5358.

Arenas, E.H. \& Trinidad, T.P., 2017b, 'Acute effects of thermally processed pili (Canarium ovatum, Engl.) pomace drink on plasma antioxidant and polyphenol status in humans', Avicenna J Phytomed. 7, 467-476.

Aril-dela Cruz, J.V., Bungihan, M.E., dela Cruz, T.E.E. \& Sagum, R.S., 2018, 'Canarium ovatum Engl. (Pili) exocarp crude extract as functional food colorant incorporated in yogurt developed product', Food Research. 2, 89-98.

Azlan, A., Prasad, K.N., Khoo, H.E., Abdul-Aziz, N., Mohamad, A., Ismail, A. \& Amom, Z., 2010, 'Comparison of fatty acids, vitamin $E$ and physicochemical properties of Canarium odontophyllum Miq. (dabai), olive and palm oils', J. Food Compos. Anal. 23, 772-776. 
Bai, S.H., Darby, I., Nevenimo, T., Hannet, G., Hannet, D., Poienou, M., Grant, E., Brooks, P., Walton, D., Randall, B. \& Wallace, H.M., 2017, 'Effects of roasting on kernel peroxide value, free fatty acid, fatty acid composition and crude protein content', Plos One. Doi: 10.1371/journal.pone.0184279.

Bandaranayake, W.M., 1980, 'Terpenoids of Canarium zeylanicum', Phytochemistry. 19, 255-257.

Basri, D.F. \& Sandra, V., 2016, 'Synergistic interaction of methanol extract from Canarium odontophyllum Miq. leaf in combination with oxacillin against Methicillin-Resistant Staphylococcus aureus (MRSA) ATCC 33591', Int J Microbiol. Doi: 10.1155/2016/5249534.

Betts, M.J. \& Russell, R.B., 2003, 'Amino acid properties and consequences of substitutions', in Michael R. Barnes \& Ian C. Gray, Bioinformatics for Geneticists. pp, 289-314, John Wiley \& Sons, Ltd., New Jersey.

Boorsma, W.G., 1914, ' The kernels of Canarium commune as an addition to milk in infant feeding',

https://pdfs.semanticscholar.org/.../a704034 fbc8a8e648090e, diakses pada 14 Februari 2018.

Bruckner, G., 2008, 'Fatty acids and cardiovascular disease', in Chow C.K, Fatty Acids in Foods and Their Health Implication. pp. 1069, CRC Press, Boca Raton.

Chew, L.Y., Prasad, K.N., Amin, I., Azrina, A. \& Lau, C.Y., 2011, 'Nutritional composition and antioxidant properties of Canarium odontophyllum Miq. (dabai) fruits', J. Food Compos. Anal. 24, 670-677.

Chua, H.P., Nicholas, D. \& Yahya, M.N.A., 2015, 'Physical properties and nutritional values of dabai fruit (Canarium odontophyllum) of different genotypes', J. Trop. Agric. and Fd. Sc. 43, 1-10.

Djarkasi, G.S.S., Nurali, E.J.N., Sumual, M.F. \& Lalujan, L.E., 2011, 'Analysis of bioactive compound in canarium nut (Canarium indicum L), Research Final Report, Tropical Plant Curriculum Project in cooperation with USAID-Texas A\&M University, Sam Ratulangi University.

Dubois, V., Breton, S., Linder, M., Fanni, J. \& Parmentier, M., 2007, 'Fatty acid profile of 80 vegetable oils with regard to their nutritional potential', Eur J Lipid Sci Technol. 109, 710-732.
Dzotam, J.K., Touani, F.K. \& Kuete, V., 2016, 'Antibacterial activities of the methanol extracts of Canarium schweinfurthii and four other Cameroonian dietary plants against multi-drug resistant Gram-negative bacteria', Saudi J Biol Sci. 23, 565-570.

Evans, B., 1994, 'Overview of Resource Potential for Indigenous Nut Production in the South Pacific', in M. L. Stevens, R. M. Bourke \& B. R. Evans (eds.), South Pacific Indigenous Nuts Proceedings, Le Lagon Resort, Port Vila, Vanuatu, October 31-November 4, 1994, pp. 11.

He, Z. \& Xia, W., 2007a, 'Nutritional composition of the kernels from Canarium album L.', Food Chem. 102, 808-811.

He, Z. \& Xia, W., 2007b, 'Analysis of phenolic compounds in Chinese olive (Canarium album L.) fruit by RPHPLC-DAD-ESIMS', Food Chem. 105, 1307-1311.

Heyne, K., 1987, Tumbuhan Berguna Indonesia, Yayasan Sarana Wana Jaya, Jakarta.

Ito, M., Shimura, H., Watanabe, N., Tamai, M., Harada, K., Takahashi, A., Tanaka, Y., Arai, I., Pei-ling, Z., Chang, R., Wei-ming, C., Jun-shan, Y., Ya-lun, S. \& Yu-lan, W., 1990, 'Hepatoprotective compounds from Canarium album and Euphorbia nematocypha', Chem. Pharm. Bull. 38, 2201-2203.

Kakuda, Y., Jahaniaval, F., Marcone, M.F., Montevirgen, L., Montevirgen, Q. \& Umali, J., 2000, 'Characterization of pili nut (Canarium ovatum) oil: Fatty acid and triacylglycerol composition and physicochemical properties', J Am Oil Chem Soc. 77, 991-997.

Kamtchouing, P., Kahpui, S.M., Dzeufiet, P.D.D., T'edong, L., Asongalem, E.A., Dimo, T., 2006, 'Anti-diabetic activity of methanol/methylene chloride stem bark extracts of Terminalia superba and Canarium schweinfurthii on streptozotocininduced diabetic rats', J Ethnopharmacol. 104, 306-309.

Khoo, H.E., Azlan, A., Ismail, A., Abas, F. \& Hamid, M., 2014, 'Inhibition of oxidative stress and lipid peroxidation by anthocyanins from defatted Canarium odontophyllum pericarp and peel using in vitro bioassays', Plos One. Doi:10.1371/journal.pone.0081447.

Koudou, J., Abena, A.A., Ngaissona, P. \& Bessie`re, J.M., 2005, 'Chemical composition and pharmacological activity of essential oil of Canarium schweinfurthii', Fitoterapia. 76, 700-703. 
Kuete, V., Sandjo, L.P., Mbaveng, A.T., Seukep, J.A., Ngadjui, B.T. \& Efferth, T., 2015, 'Cytotoxicity of selected Cameroonian medicinal plants and Nauclea pobeguiniitowards multi-factorial drugresistant cancer cells', BMC Complement Altern Med. Doi: 10.1186/s12906-0150841-y.

Kuo, CT., Liu, TH., Hsu, TH., Lin, FY. \& Chen, HY., 2015, 'Antioxidant and antiglycation properties of different solvent extracts from Chinese olive (Canarium album L.) fruit', Asian Pac J Trop Med. 8, 1013-1021.

Leakey, R., Fuller, S., Treloar, T., Stevenson, L., Hunter, D., Nevenimo, T., Binifa, J. \& Moxon, J., 2008, 'Characterization of treeto-tree variation in morphological, nutritional and medicinal properties of Canarium indicum nuts', Agroforest Syst. $73,77-87$.

Lim, T.K., 2012, Edible Medicinal and NonMedicinal Plants, Springer, Netherlands.

Lv, Z., Chen, K., Zeng, Y. \& Peng, Y., 2011, 'Nutritional composition of Canarium pimela L. kernels', Food Chem. 125, 692695.

Massimo, C., Lucio, T., Jesus, M.A., Giovanni, L. \& Gluseppe, C., 2009, 'Extra virgin olive oil and oleic acid', Nutricion Clinica Dietetica Hospitalaria. 29, 12-24.

Millena, C.G. \& Sagum, R.S., 2018, 'Philippine Pili (Canarium ovatum, Engl.) varieties as source of essential minerals and trace elements in human nutrition', $J$ Food Compos Anal. 69, 53-61.

Mogana, R. \& Wiart, C., 2011a, 'Canarium L.: A phytochemical and pharmacological review, J. Pharm Res. 4, 2482-2489.

Mogana, R., Teng-Jin, K. \& Wiart, C., 2011b, 'In vitro antimicrobial, antioxidant activities and phytochemical analysis of Canarium patentinervium Miq. from Malaysia, Biotechnol Res Int. Doi:10.4061/2011/768673.

Mogana, R., Teng-Jin, K. \& Wiart, C., 2013a, 'Antiinflammatory, anticholinesterase, and antioxidant potential of scopoletin isolated from Canarium patentinervium Miq. (Burseraceae Kunth)', Evid-Based Complement. Altern. Med. Doi: $10.1155 / 2013 / 734824$.

Mogana, R., Teng-Jin, K. \& Wiart, C., 2013b, 'The medicinal timber Canarium patentinervium Miq. (Burseraceae Kunth.) is an antiinflammatory bioresource of dual inhibitors of cyclooxygenase (COX) and 5- lipoxygenase (5-LOX), ISRN Biotechnol. Doi: 10.5402/2013/986361.

Mogana, R., Adhikari, A., Debnath, S., Hazra, S., Hazra, B., Teng-Jin, K. \& Wiart, C., 2014, 'The antiacetylcholinesterase and antileishmanial activities of Canarium patentinervium Miq.' BioMed Res Int. Doi: $10.1155 / 2014 / 903529$.

Osborn, H.T. \&Akoh, C .C., 2002, 'Structured lipidsnovel fats with medical, nutraceutical, and food applications', Compr Rev Food Sci F Safety. 3, 110-120.

Pham, L.J. \& Dumandan, N.G., 2015, 'Philippine Pili: Composition of the lipid molecular species', J Ethn Foods. 2, 147-153.

Prasad, K.N., Chew, L.Y., Khoo, H.E., Kong, K.W., Azlan, A. \& Ismail, A., 2010, 'Antioxidant capacities of peel, pulp, and seed fractions of Canarium odontophyllum Miq. fruit', J Biomed Biotechnol. Doi:10.1155/2010/871379.

Prasad, K.N., Chew, L.Y., Khoo, H.E., Yang, B., Azlan, A. \& Ismail, A., 2011, 'Carotenoids and antioxidant capacities from Canarium odontophyllum Miq. fruit', Food Chem. 124, 1549-1555.

Rahman, H., Tursino, Sitompul, J.P., Anggadiredja, K. \& Gusdinar, T., 2015, 'The nutritional fatty acids profile and physicochemical properties of Canarium indicum nut oil', Int J Pharmacogn Phytochem Res. 7, 12221226.

Rahman, H., Sitompul, J.P., Anggadiredja, K., Lee, H.W. \& Gusdinar, T., 2016, 'The stereospecific analysis of Canarium indicum oil-fatty acid based in triglycerides using high-performance liquid chromatography', Int J Pharm Clin Res. 8 (Suppl), 403-406.

Saari, S.M., Basri, D.F., Budin, S.B., Abd Warif, N.M., 2017, 'Effects of Canarium odontophyllum leaves on plasma glucose and $\mathrm{T}$ lymphocyte population in streptozotocin-induced diabetic rats', Saudi J Biol Sci. 24, 320-323.

Seneviratne, K.N. \& Kotuwegedara, R.T., 2009, 'Canarium zeylanicum seed oil: An edible oil with beneficial qualities', Int J Food Sci Technol. 44, 792-798.

Seukep, J.A., Ngadjui, B. \& Kuete, V., 2015, 'Antibacterial activities of Fagara macrophylla, Canarium schweinfurthii, Myrianthus arboreus, Dischistocalyx grandifolius and Tragia benthamii against multi-drug resistant Gram-negative bacteria', SpringerPlus. Doi: 10.1186/s40064-015-1375-y. 
Shakirin, F.H., Prasad, K.N., Ismail, A., Yuon, L.C. \& Azlan, A.,2010, 'Antioxidant capacity of underutilized Malaysian Canarium odontophyllum (dabai) Miq. fruit', J Food Compost Anal. 23, 777-781.

Shakirin, F.H., Azlan, A., Ismail, A., Amom, Z. \& Yuon, L.C., 2012a, Protective effect of pulp oil extracted from Canarium odontophyllum Miq. fruit on blood lipids, lipid peroxidation, and antioxidant status in healthy rabbits', Oxid Med Cell Longev. Doi:10.1155/2012/840973.

Shakirin, F.H., Azlan, A., Ismail, A., Amom, Z. \& Yuon, L.C., 2012b, 'Antiatherosclerotic effect of Canarium odontophyllum Miq. fruit parts in rabbits fed high cholesterol diet', Evid-Based Complement Alternat Med. Doi:10.1155/2012/838604.

Stangeland, T., Remberg, S.F. \& Lye, K.A., 2009, 'Total antioxidant activity in 35 Ugandan fruits and vegetables', Food Chem. 113, 8591.

Tamai, M., Watanabe, N., Someya, M., Kondoh, H., Omura, S., Ling, Z.P., Chang, R. \& Ming, C.W., 1989, 'New hepatoprotective triterpenes form Canarium album', Planta Med. 55, 44-47.

Thomson, L.A.J. \& Evans, B., 2006, 'Canarium indicum var. indicum and $C$. harveyi (canarium nut) Burseraceae (torchwood family)', https://www.doc-developpementdurable.org/.../Canarium-ca..., diakses pada 14 Februari 2018.

Wen, L., Lin, S., Zhu, Q., Wu, D., Jiang, Y., Zhao, M., Sun, J., Luo, D., Zeng, S. \& Yang, B., 2013, 'Analysis of Chinese olive cultivars difference by the structural characteristics of oligosaccharides', Food Anal. Methods. 6,1529-1536.

Wu, G., 2013, 'Functional amino acids in nutrition and health', Amino Acids. Doi: 10.1007/s00726-013-1500-6

Wu, J., Fang, X., Yuan, Y., Dong, Y., Liang, Y., Xie, Q., Ban, J., Chen, Y. \& Lv, Z., 2017, 'UPLC/Q-TOF-MS profiling of phenolics from Canarium pimela leaves and its vasorelaxant and antioxidant activities', Rev Bras Farmacogn. 27, 716-723.

Yeh, Y., Chiang, A. \& Hsieh, S., 2017, 'Chinese olive (Canarium album L.) fruit extract attenuates metabolic dysfunction in diabetic rats', Nutrients. Doi:10.3390/nu9101123.

Yeh, Y., Cho, Y., Hsieh, S. \& Chiang, A., 2018, 'Chinese olive extract ameliorates hepatic lipid accumulation in vitro and in vivo by regulating lipid metabolism', Scientific Reports. Doi:10.1038/s41598-018-19553-1.

Youmsi, R.D.F., Fokou, P.V.T., Menkem, E.Z., Bakarnga-Via, I., Keumoe, R., Nana, V. \& Boyom, F.F., 2017, 'Ethnobotanical survey of medicinal plants used as insects repellents in six malaria endemic localities of Cameroon', J Ethnobiol Ethnomed. Doi: 10.1186/s13002-017-0155-X.

Zhang, L. \& Lin, Y., 2008, 'Tannins from Canarium album with potent antioxidant activity', $J$ Zhejiang Univ Sci B. 9, 407-415. 